Each Volunteer serves a minimum of two years and may stay on longer to see his project completed or handed over to competent successors--either trained local citizens or, in their absence, new Volunteers. Quite often, if the Volunteer does not already have a Ph.D., he or she uses data collected during this service towards attaining that degree.

Most of the environmental Volunteers have a good experience, advancing their professional careers while broadening their personal experience, but the question has been asked as to whether the countries in which they work derive comparable benefits.

Everyone knows of the waves of ecological concern now sweeping across industrialized nations. Fewer people are aware of the environmental dangers confronted by the rest of the world as it attempts to achieve similar status. Crash programmes to catch up on development can be so destructive of natural resources that they may actually constitute serious steps backwards.

Fortunately, an increasing number of leaders in developing nations are realizing that there are economic as well as aesthetic reasons to pause and evaluate conditions and consequences before launching programmes that topple forests, erode land, silt rivers, foul air and water, destroy populations or even whole species of plants or animals, and leave layers of pesticide to upset ecosystems.

It is, however, not enough that these enlightened leaders want to do things properly: they must have people with the skills and knowledge needed to minimize the environmental impact of the expanded expectations of the world's burgeoning population. To find these skills, the developing nations are turning to international agencies such as the United Nations, the World Bank, I.U.C.N., and private foundations who in turn often use the Smithsonian-Peace Corps Program as a source of personnel.

'Now most people realize that the Peace Corps has a legitimate interest in careful development and that its ability to tap the pool of talented and concerned people currently receiving degrees in environmental sciences in the United States makes it a logical resource for staffing both its own projects and those initiated and sometimes funded by other organizations', says Dr James A. Sherburne, the Program's
Manager. He cites as one example the F.A.O.'s ecological study of the Okavango Delta in Botswana, which is staffed in part by Smithsonian-Peace Corps Volunteers.

Wildilife conservation and national park development is one of the programme's major interests, involving approximately 30 Volunteers currently in the field. They include John Paxton, who, as one of the first, it not actually the first, trained Park Naturalist to be employed in Thailand and perhaps in all of south-east Asia, started a library, herbarium, and visitor centre, while making significant discoveries about the movement of elephant herds; also Rodney Flynn in Malaysia who is helping with plans to save the endangered Sumatran Rhinoceros, Dicerorhinus (Didermoceros) sumatrensis, from extinction. The Smithsonian-Peace Corps Program's efforts in faunal protection have been lauded by international wildlife preservation leaders.

Other projects deal with Man's use and abuse of his resources. One Volunteer, for instance, is investigating whether fish can be used for mosquito control in the Lake Maracaibo drainage system of Venezuela, while two others analyze water quality and monitor atmospheric emissions around Brazil's Baia de Guanbara.

Sherburne foresees steady growth for the programme as the Peace Corps responds to new requests for scientific personnel. In conjunction with this expected growth, the programme is expanding its efforts to identify and help define viable projects before Volunteers are assignzd, to extend and further specialize its recruiting techniques, to provide appropriate training before Volunteers go overşeas, and to improve its technical and material support when once they are functioning in their jobs. The programme staff would welcome inquiries from persons who could offer technical advice to Volunteers about their projects in exchange for current information from the field.

LAWRENCE D. R ITTER
Smithsonian-Peace Corps Environmental Program
Smithsonian Institution
Washington
D.C. 20560 , U.S.A.

\title{
International Wetlands Convention in Force
}

The recent coming into force of the first international convention for conservation of marshes, bogs, and lakes, has been very widely welcomed by conservation organizations and biologists as well as by naturalists. For these 'wetlands' are considered to be among the most important but seriously threatened natural areas in Europe and many other parts of the world.

The Convention on Wetlands of International Importance was completed at Ramsar, Iran, in 1971, and provides for international action to safeguard wetlands-because of their high biological productivity, which in many cases is an essential factor in the support of commercial fisheries, and of their importance for science, ecological understanding and education, and human recreation. Wetlands are also of great importance as refuges for waterfowl, especially during their annual migrations between breeding and wintering grounds.

The parties to the convention, which actually came into force on 21 December 1975, are Australia, Bulgaria, Finland, Greece, Iran, Norway, South Africa, and Sweden. Other countries which have already signed, indicating an intention to accede to the Convention, are Belgium, Federal Republic of Germany, Ireland, Italy, Netherlands, Switzerland, USSR, and United Kingdom.
Our viewpoint from WWF/IUCN is that, while welcoming the Convention, we must express regret at the few countries which have accepted it so far. Wetlands are not wastelands to be dredged, drained, filled in, or used as rubbishdumps: they are vital areas in the human and natural environment and need careful conservation. All governments should accede to the Convention as soon as possible.

IUCN has already compiled a directory of wetlands of international importance in Europe and North Africa, and the list is being extended to other parts of the world.*

Organizations associated with the preparation of the Convention, apart from IUCN and WWF, were the International Waterfowl Research Bureau, the International Council for Bird Preservation, the Conseil International de la Chasse, FAO, and UNESCO.

\author{
PETER F. R. JACKSON, Director of Information \\ World Wildlife Fund \\ 1110 Morges \\ Switzerland.
}

* Note, also, Dr Julian Rzóska's account of 'Conservation of Inland Waters', and particularly of 'Project Aqua', published on page 46 of this issue.--Ed. 